

Jost Reischmann ${ }^{1}$

Bamberg University, Germany

\title{
What are Andragogues good for? Workplaces, Competencies, Study Contents, Identity
}

\begin{abstract}
This paper wants to strengthen the identity of Andragogues - to make Andragogues strong and proud. It starts from the observation, that the term "adult educator" labels many different functions, roles, competencies, and educational backgrounds - which leads to an unclear identity. To shape the identity it is suggested to differentiate the various groups of individuals working in this field; the focus is on the graduates of university programs: Andragogues. Workplaces are described as places where graduates of university programs can be found working successfully. Four competencies are identified needed at these workplaces: teaching, organizing, consulting, and evaluation. These competences have to be included in the education of Andragogues. The question is asked: is there a "unifying concept" for people working in that field, a shared identity? The answer will be: what is unifying is the idea, the need, and the function to organize change: for individuals, for organizations, for society. Andragogues - no matter were they work - are change specialists. To strengthen the self-understanding, the identity of the professionals, graduated from university programs and educated for this complex task (and to discriminate them from "everybody" doing some sort of adult education), this group should use the name/label "Andragogue". And to feel strong and proud: In a changing world change specialists are bitterly needed.
\end{abstract}

Keywords: andragogues, adult educators, professional identity, the compentences of andragogues, unifuying concept for adult educators.

\footnotetext{
${ }^{1}$ Prof. (em.) Dr. Jost Reischmann was Chair of Andragogy at Bamberg University in Germany from 1993 to 2008 (jost.reischmann@uni-bamberg.de). He was President and Vice-president of the International Society for Comparative Adult Education (ISCAE - www.ISCAE.org). In 1999 he was nominated and inducted in the International Adult and Continuing Education Hall of Fame, 2006-2012 member of its Board of Directors. In 1998 he received the 'Presidents Award for Innovative Leadership' and in 2006 the 'Outstanding Service Award' from the American Association for Adult and Continuing Education.
} 


\section{Introduction}

It is strange: data and experience worldwide document that adult education in volume, scope, public, financing, economic and political perception has clearly grown. But in spite of this positive development in many countries the professional academic graduates are missing a feeling of unity or identity, as Kleisz states for Hungary: "The younger and trained generation does not feel the unity of profession" (Kleisz, 2015, p. 22). In spite of the positive development in reality still the critical question remains - from outside but as well from inside the profession: what are Adult Educators/Andragogues good for? And what is their identity?

\section{Threats for identity}

A number of reasons may count for the fragile identity. Just to name some:

\section{Everybody is an "Adult Educator"}

Who is an Adult Educator? The answer is easy: everybody. In the everyday perception "everybody" can be labeled as "adult educator":

- the grandma sharing her knowledge of baking cookies,

- the engineer instructing his staff about a new technology,

- the political or religious missionary preaching at the marketplace or in TV about the true and only life or society,

- salespersons, police, medicine, media, tourism, priests, ... ("implicit" adult educators),

- the hundred thousand teachers in adult education institutions (community, church, business and industry, museums, music schools, etc.), teaching some hours at night what they feel they can teach - volunteers, not paid, or trainers, paid (poorly) per hour/day.

A similar confusing picture can be found when looking at conferences (i.e. $6^{\text {th }}$ and $11^{\text {th }}$ Standing Conference on the History of Adult Education, Jena, Germany 1996; Bamberg, Germany 2006) that describe "leading personalities in adult education": from "the Wise", over humanists, organizers to professors a high number of "prototypes" are presented under the label of "Adult Educator". 
So: just "everybody" can be an "Adult Educator". But: an identity of "everybody" is not possible! Perhaps it would help to clarify the identity if the various groups working in this field would be discussed separately (i.e. teachers, trainers, administrators, volunteers, full-time employees, university graduates, etc.).

\section{No obligatory education}

Looking to the academic preparation of teachers in Adult Education also shows no shared background or identity. In a recent study, Martin et al. (2017, p. $115, \mathrm{n}=3961$ ) prove that only about one third of the teachers in (public) adult education have some sort of educational academic background (it might be telling that a separate category "study in andragogy/adult education" was not even posed!):

- education full subject:

$16,3 \%$

- education as side subject: $\quad 7,0 \%$

- not-educational degree: $\quad 33,3 \%$

- no academic degree: $\quad 33,4 \%$

A slightly more positive picture was showed by the participants in a recent conference (International Scientific Conference on Adult Education: "Developing and understanding Professional Identity of Adult Educators", Rijeka 2017): half of the participants have graduated in pedagogy or andragogy.



Figure 1: Educational background of participants of the Conference 2017 
Asking for the professionalization of this field these results show that we are still at the beginning. The idea of a shared qualification is still a task to come. While other professions like medicine, law, or engineering have clear and compulsory educational criteria for their identity, an identity for Adult Education cannot be based on a shared education for this field.

\section{Plurality of functions and workplaces of Andragogues}

But even in the group of graduates of university programs of adult education/ andragogy the workplaces give no clear picture that could form identity: starting with the belief that our university program ("Chair of Adult Education") was to educate teachers for adults, our experiences around 1995 were shocking: We asked our students some years after graduation: "What is your workplace now - after finishing your studies?" The shocking answer was: only a small portion (10-30\%) was employed in a teaching position at an adult education institution - most of the "adult educators" did not teach! 20-30\% of our graduates work as freelanced workers ("training, development, counselling/consultancy"), about 10-20\% have a career at colleges/universities (Bender et al., 2008). Other programs at other universities reported similar results. Horror: did we educate our students for unemployment or cab driving?

This "horror" gladly could be disproved by another result of our and others' research: The graduates overwhelmingly let us know they had no problem finding a well paid workplace, are happy with their employment, and feel that our program prepared them well for their specific workplaces!

However: asking for the name of their workplaces we still got a vast and confusing variety of descriptions: teacher, trainer, evaluator, coach, moderator, HRD-employee, manager, administrator, personal or organizational developer. Just to give some examples:

- Antje is working as a freelance worker; she founded the institute for "artdialogue" (continuing education for art- and cultural managers)

- Sabine (freelance worker) is communication trainer "clarifying and solving difficult communication situations" for individuals and institutions.

- Yvonne was employed by a local brewery as a manager.

- Helga offers conflict management training in business and industry and reported how she solved a conflict that had cost five million EUR the year before! 
It seems we taught our students competences useful in many fields of the job market, and in the beginning did not really know what these competences were. We will come back to this problem later.

Even vaster and more confusing was the answer in response to the question of which institutions they work in: in business and industry, adult education centres, health-care, charities, cultural institutions, churches, in armed forces, management and media, in tourism, journalism and many other fields ... This confirms that Andragogues are beneficial in many fields, but the disadvantage remains: they are not perceived as experts in one specific workplace or direction - and sometimes they themselves are not clear about that. So the functions, workplaces, and institutions do not offer a unifying identity.

Threatening an identity is in addition the fact, that Andragogues are often seen limited to one segment of the field (which could be social change, or second chance/compensatory education, or community education, or political education, or cultural capital, or human resource development, or 'learning to acquire employability', or minority education - just to name some). Depending of the money-giver or what is in a certain time in fashion one segment is in an oversimplified way claimed to be the total, and the others are either not seen or not valued.

Carroll Londoner, past chair of the International Adult Education Hall of Fame $^{2}$ outlines this problem for the USA (private mail Jan. 31, 2014): "The adult education programs in the States have shrunk dramatically as the universities do not seem inclined to support adult education because they do not understand it. They have too quickly identified the broad field of adult education with the notion of 'adult literacy' ... We in the universities have not done a very good job of explaining to our administrators what the broad field is about and why it should be studied academically".

It is a mistake to perceive and value just one segment as the only legitimate field for Andragogues. The study of andragogy opens the doors to a growing number of workplaces, in different settings and functions, and with a catalogue of needed competencies. Again: this plurality is an advantage of andragogy. And at the same time again a disadvantage, because it is difficult to perceive that all these different fields belong to a shared identity: adult education, andragogy.

We also can refer to statistics that show us that Andragogues fulfil a number of different tasks: Martin et. al. (2017, p. 99), asking 5244 individuals in

2 http://www.halloffame.outreach.ou.edu 
adult education, could prove that people working in adult education institutions fulfill in their daily work a number of different activities:
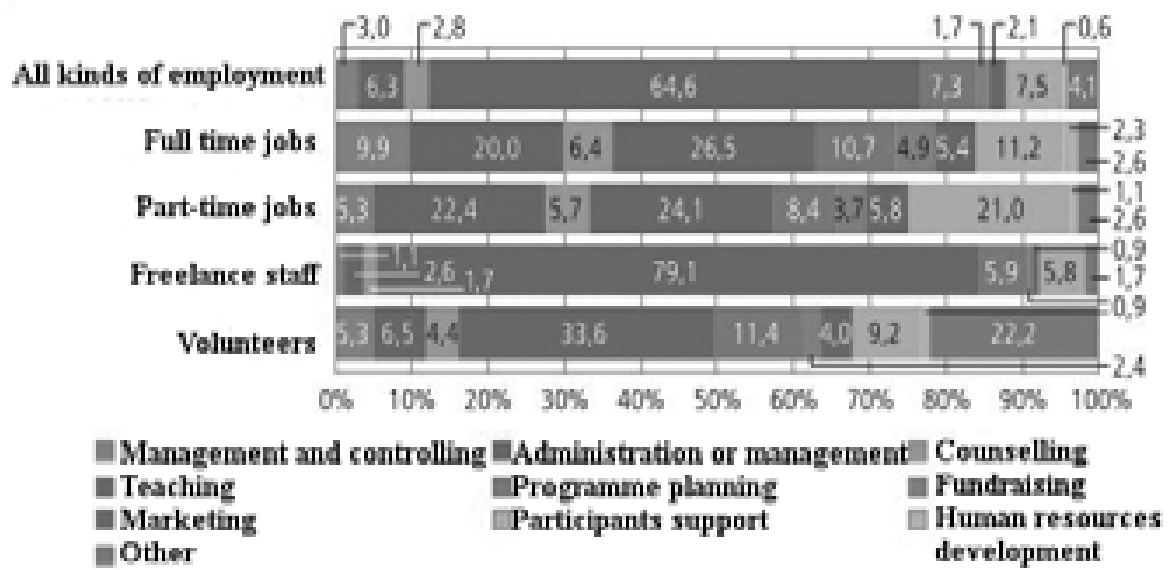

Comment: Input data: wb-perzonalmonitor 2014 (lewel $\mathrm{l}$ ); own calculation; $n=$ 5.244: value in percent

Figure 2: Activities of fulltime-employees in adult education institutions

Full-time employees spend 9,9\% of their time for management or controlling, $20 \%$ for administration, $6,4 \%$ for consulting, $26,6 \%$ for teaching, $10,7 \%$ for program-planning, 4,9\% for acquisition, 5,4\% for marketing, $11,2 \%$ for assisting participants, $2,3 \%$ for staff development.

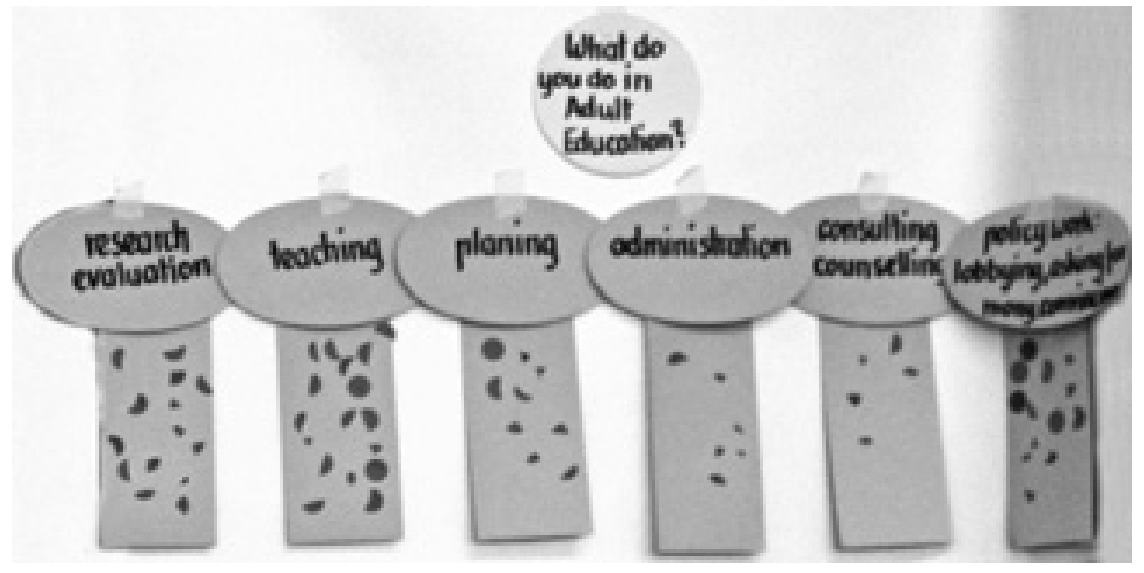

Figure 3: Activities of Adult Education conference-participants 
Non-representative, but still confirming are the answers we got at a recent conference (International Scientific Conference on Adult Education: "Developing and understanding Professional Identity of Adult Educators", Rijeka 2017): working in adult education needs from the same person a number of activities and competencies

A simplified perception may perceive this as confusing or "borderless". But this plurality of functions describes the reality of the workplaces in adult education: that is what Andragogues do.

\section{Summary}

The institutions and workplaces Andragogues work in, the education they have, are manifold, different - far more than the traditional "teacher of adults" in adult education institutes. That means: institutions, workplaces, education, and functions do not constitute an identity.

As it was suggested earlier in the text, it might be helpful for clarifying the identity if the various groups of individuals working in this field would be discussed separately. Putting the focus of this paper on academic educated graduates the unclear borderless term "Adult Educator" makes it difficult to differentiate this group from "everybody"; that makes the term "Adult Educator" destructive for the perception and identity of our discipline and our graduates (Reischmann, 2015b). In a consequence: to describe and guarantee quality standards, to claim academic theory and research, and especially to grow an own identity and offer a unique and specific "label" in the labour-market, I changed 1996 the name of my chair in Bamberg from "Adult Education" (Erwachsenenbildung) to "Andragogik" (Andragogy). Andragogy is the educational discipline, the subject of which is the study of lifelong and lifewide learning and education of adults (Savicevic, 1999; Reischmann, 2004; Henschke, n.d.). The following will focus on the group "graduates of university programs of adult education/ andragogy".

It might be helpful to draw an analogy to the identity of other recognized professions like medicine, law, architecture, and engineer. A “Mediziner" (German) = doctor, physician, health professional is not "everybody" doing something for health, but exclusively experts that studied this subject. Even there it took centuries to install this identity: In the corpus of the German language the frequency of the term "Mediziner" was 2 (per million tokens) in 1800 (= "nearly unknown"), 4 in 1900, and increased to 19 in 2000 (see Figure 4). May be we will see a similar development with "Andragogue" in the time to come. 


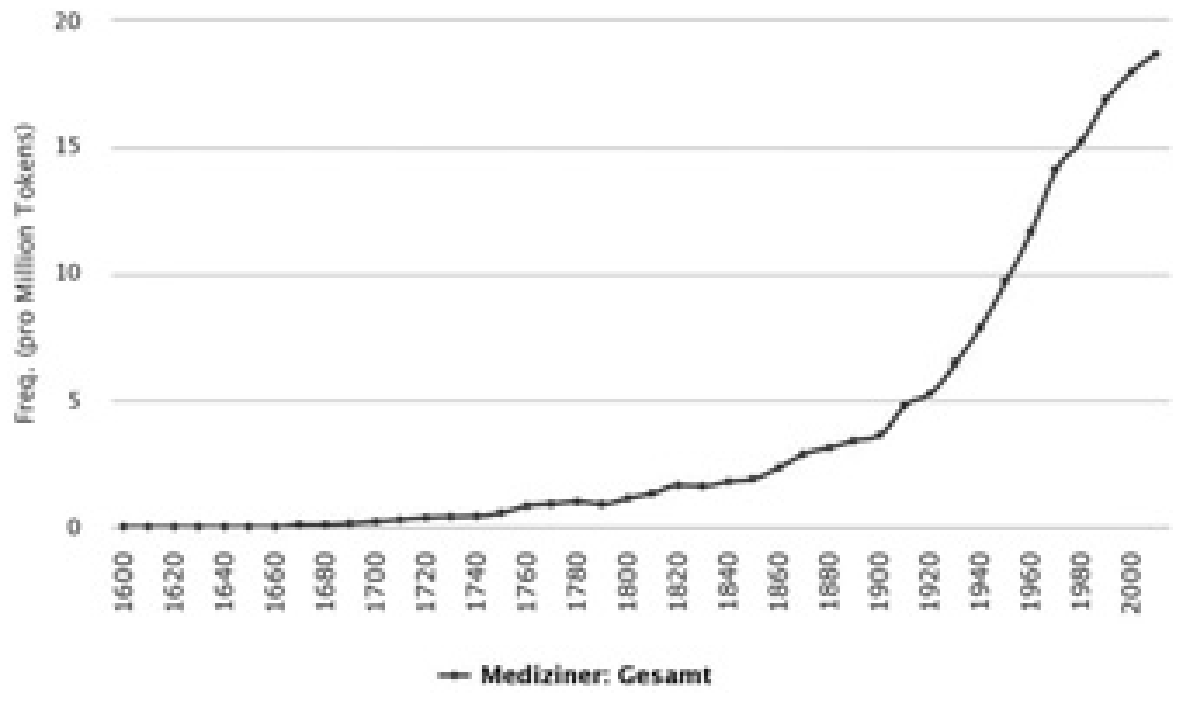

Figure 4: The term "Mediziner" (Doctor) - Development Curve Source: DWDS - Verlaufskurve, 2017

But referring to the described multitude of functions and workplaces it also can be summarized already now: There exists a unifying idea/concept of all these workplaces: Andragogues teach, organize, manage, inform, mediate, moderate, motivate, and interfere in various ways in tensions, conflicts, friction between:

- people and people; or

- people and organizations; or

- people and things; or

- organizations and organizations.

This widespread usefulness of Andragogues can be seen as a strength, value - and identity (Reischmann, 2015a).

\section{What do Andragogues do?}

\section{What are their (needed/given) competencies?}

The reports we received from our graduates (Bender et. al., 2008) parallel to the insights from theory and research, made us analyze, what in the multitude of workplaces andragogues do, what they need for their daily work. We identified 
four core competencies, which consequently became a part of our curriculum in addition to the traditional contents - to enable our students/graduates to act as professionals in the wide field of lifewide education:

- First, it is expected that an Andragogue is able to teach. We found that teaching was often a starting point for our graduates, but that after a short while they moved up into a supervising, planning, managing position. However, even in this position it is expected that they can convincingly "teach" and advise others how to teach ("train the trainer" programs).

- Second, we have to prepare them for planning, organizing, and managing programs and measures. The success of an educational program does not only depend on the quality of teaching (micro-didactics), but also on the learning-supportive planning and organizing of the program (macro-didactics): How can learning be started and supported by organizational measures? This includes the challenge how learning occasions can be identified and supported in workplaces, cultural institutions, hospitals, tourist places, hospitals, political and religious organizations etc.

- Third, they need the ability to consult and counsel (moderator - counsellor - consultant - mediator - coach). The manifold learning challenges in "lifewide education" (Reischmann, 1986; Jackson, 2012) opened the insight into a new role of Andragogues: not presenting/transporting knowledge (teaching), but helping persons or groups to find their way and solve their problems by counselling/consulting strategies - often in a one-to-one-situation.

- And finally, they must be able to do evaluation and research. This ability is not only expected from scholars and members of research-organizations, but is also needed in the practical work in many positions and organizations for needs-assessment, evaluation and quality control, planning of (political, strategic) programs and feedback to organizers and boards.

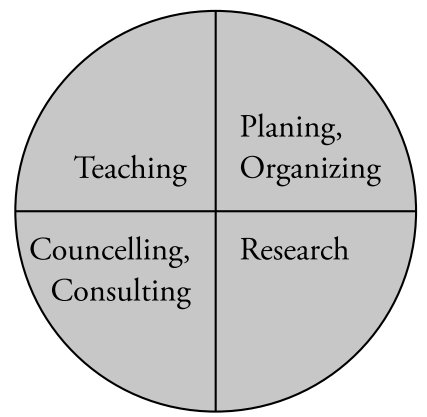

Figure 5: Core competencies of Andragogy Curriculum Bamberg University 


\section{How to learn these competencies?}

"Competencies" in our understanding includes the capability to perform (practice) and to reflect (theory). Similarly to other professions (medical doctors, lawyers, architects...), it is not enough that Andragogues have knowledge; professionals also have to be able to act in their field. These competencies do not come by themselves. For the ability to perform we developed so-called competencytrainings. They usually last three full days, filled with acting, training, trying, and demonstrating, and are limited to not more than 20 students. These three days are theory-reduced and focus on performance. Of course these competency-based classes have to be supplemented with the "normal" knowledge- and theory-oriented classes, lectures, and readings. Performance has to be melted in and interwoven with knowing and understanding to lead to competency. These competency-trainings cover:

- "Visualising, presentation, moderation". Here, students learn to stand in front of a group, design presentation-material, work with an auditory, present learning material, and interact with groups - also in conflict situations.

- In a second module they learn how to design classes and seminars.

- The module "program-planning" supplies planning/organizing strategies. An important role for this competency also plays the internship each of our students has to go through.

- "Communication competency" is a module in the competency "consulting / counselling", another module is "consulting-strategies and-techniques".

- In the competency-training "coaching" they learn to support individual trainers and managers to solve practical problems.

In all these classes students learn an active, acting approach to solving problems of people and institutions in a professional way.

At the end of the final examination, we sometimes ask our students what in their perception has been the most important part of their study. The majority names the competency-trainings. This is also true for our alumni, when asked years after graduation. It seems that the preparation to perform successfully and professionally in the practical field adds an important factor to their identity and employability. 


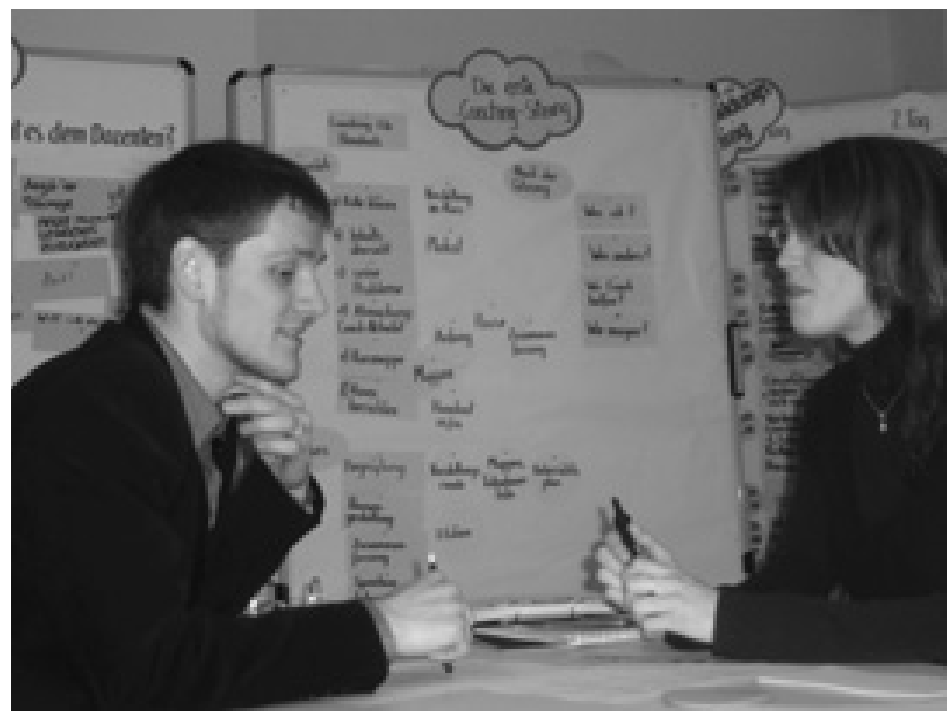

Figure 6: Mutual planning of subject matter specialist and coach (Andragogue)

\section{Summary}

Andragogues are beneficial in manifold positions and institutions - this can be easily proved by monitoring the workplaces they are in and the activities they perform there. The reality of the workplaces of Andragogues shows a wide variety of functions and activities:

- They have to practically perform and theoretically reflect.

- They need the competencies to a) professionally teach, b) plan and organize learning, c) consult and moderate, d) evaluate and research.

- And they have to produce the most successful mix of these ingredients.

To make Andragogues perceived as professionals they not only need knowledge, but they also need performance skills. This has to be incorporated into the curricula of the University programs (and/or continuing professional education). And to be aware that for the complex tasks not only one, but all these competencies are needed. 


\section{The shared identity: Change specialist}

Using this complex observation of different workplaces, functions, organizations, competencies, and expectations the question is asked: is there a "unifying concept" for people working in that field? Is a shared identity possible?

The answer for me is: unifying this - sometimes confusing - variety is the idea, the need, and the function to organize change: for individuals, for organizations, for society. Andragogues - no matter were they work in business and industry, cultural organizations, hospitals or the armed forces, tourism or media, political or social institutions - are change specialists.

This world, in which we live, is full of change. And change deserves learning - throughout life, lifewide. Change specialists ask and answer questions as:

- What effect, impact, transfer is needed? And how can it be reached successfully?

- What is that good for? For person, institution, etc.?

- What is better: More or less? Or different?

- What do THEY need? And what do they really need?

- What already exists that supports/hinders a good development?

- Could that also be seen differently? And how does the other see this?

- Where are we going to? Short-term, long-term?

- What might be understood as the message behind it? What effect will that message have that is good/bad?

- What are the advantages AND the unavoidable disadvantages of the planned action? (Persons, products, institution? Short- / middle- / long term? Who can (not) do what with whom?)

- How to you plan something that later on will be different anyway?

All these questions belong to the toolbox of Andragogues, are the daily business of Andragogues, take account of the competencies they (should have) learned. That makes them the sought specialists in the labour market. Who else asks and answers these complex questions, and who asks for the consequences from the answers and develops an action plan?

To strengthen the identity of the professionals, graduated from university programs and educated for this complex task (and to discriminate them from "everybody" doing some sort of adult education), this group should use the name/label "Andragogue".

Of course we know: We are only at the beginning of the development of this new academic discipline. In Germany it is just brief four decades ago that the first graduates in Adult Education left university. Looking to the academic 
discipline the glass can be seen half empty or half full: at many universities in many countries programs for Andragogy/Adult Education exist, as well as do research, literature, conferences, societies, journals, professors, students/graduates, and the need from the market to have the described competencies available. For the sake of developing and strengthening the identity of the Andragogues it may be more helpful to look to the "half full glass" by valuing what has already been developed. That can make self-convinced and strong, while overcritical asking what is missing makes the profession and the individuals in the profession weak.

A main starting point for further directions may not be to start with the old picture of the teacher, but with the idea of the "change specialist". This opens the perspective to many more workplaces, to new tasks, to a different curriculum. This changed perspective makes us aware of the many places in a changing world where change specialists are bitterly needed. And makes us feel strong and proud to be part of this world-moving development.

\section{Closing summary and challenges}

The field of adult learning and education and consequently the working-fields of andragogues are nowadays perceived as much wider and diversified than three decades ago, have reached new horizons. And it is perceived much more important, as UNESCO stated (The Hamburg Declaration On Adult Learning, UNESCO, 1997):

"Adult education ... is a key to the twenty-first century. ... It is a powerful concept:

- For fostering ecologically sustainable development;

- for promoting democracy, justice, gender equity, and scientific, social and economic development, and

- for building a world in which violent conflict is replaced by dialogue and a culture of peace based on justice.

- Adult learning can shape identity and give meaning to life.

Andragogues can be the specialists to support these change processes, leading into a future worth to live in.

For the academic subject "andragogy" there exist several challenges, problems, tasks: 
- to identify the specifics of the subject and the shared paradigms of andragogy and Andragogues, to discuss what Andragogues are good for, what their specific identity is, to document the results (for the outside and for self-perception), and then to convince inside and outside how important this subject is.

- To develop a curriculum including convincing competencies that respects the variety of expectations in the variety of possible workplaces.

- To be self-aware and convince others that is not confusing or "unclear", that Andragogues are beneficial in companies, churches, and culture, in armed forces and adult education centres, in management and media, in tourism, hospitals, and many other fields, but that this documents the value and richness of this complex subject and profession, and the shared vision of Andragogues as "change specialists".

- To become aware that the term "adult education/educator" is destructive for the university based profession. The term "Andragogue" could be a discriminator, a name that supports identity to the graduates and the discipline.

- And most important: to decide strategically where and when to be critical and talk about the half empty glass, and where it is more viable, more supportive for the academic subject, the students, and the field, to point out that the glass is half full, that good examples of success document the potentials of andragogy and Andragogues.

- But also: to be aware of the limitations on what can be achieved through adult education. To expect (or promise) to save with some pennies the whole world is a romantic expectation, but for sure leads to disappointment, frustration, and a ruined reputation.

This paper focussed on the graduates of university-based programs. But still needed is the whole range of adult educators at all levels and in all fields: the volunteers, the partly paid part-timers, the fully employed subject-matter-specialists, the organizers and administrators and teachers - they are all still needed (analogue to medicine, where besides the professionals = studied doctors still nurses, midwifes, ambulance-drivers etc. are needed). But it also became clear that for the complex and difficult challenges of a "society in change" in addition to professional experts - Andragogues, scientifically educated at a university are needed to support change and learning successfully to make, as UNESCO expressed it, "Adult learning: a joy, a tool, a right and a shared responsibility" (The Hamburg Declaration On Adult Learning, UNESCO, 1997).

There are many reasons to be proud and strong in this identity! 


\section{References}

Bender, W. (2008). Die Bamberger Andragogik. Studium und Berufsperspektiven in Erwachsenenbildung, beruflicher Weiterbildung und Personalentwicklung. Tönning: Der andere Verlag.

DWDS - Verlaufskurve. (n.d.). Retrieved on June 21, 2017, from https://www.dwds. $\mathrm{de} / \mathrm{r} /$ plot?q=Mediziner\&view=1 \&norm=date\%2Bclass\&smooth=spline\&genres $=0 \&$ grand $=1 \&$ slice $=10 \&$ prune $=0 \&$ window $=3 \&$ wbase $=0 \&$ logavg $=0 \&$ logscale $=0$ \&xrange $=1600 \% 3 \mathrm{~A} 2016$ )

Henschke, J. (n.d.). Andragogy Website http://www.umsl.edu/-henschke.

JaCKson, N. J. (2012). Lifewide Learning: History of an idea. The Lifewide Learning, Education \& Personal Development e-book, 1-30. Retrieved from http://www. lifewideebook.co.uk/uploads/1/0/8/4/10842717/chapter_a1_jackson.pdf

Kleisz, T. (2015). The state of profession-building in the field of Andragogy in Hungary. In N. Balasz (Ed.), International perspectives in adult education Vol. 70 (pp. 16-26). Bonn: DVV International.

Martin, A., Lencer, S., Schrader, J., Koschek, S. Ohly, H., Dobischaft, R. ... \& RoSENDAL, A. (2017). Das Personal in der Weiterbildung-Arbeits-und Beschäftigungsbedingungen, Qualifikationen, Einstellungen zu Arbeit und Beruf. Bielefeld: Bertelsmann. Retrieved from https://www.die-bonn.de/doks/2017-weiterbildner-01.pdf

Reischmann, J. (1986). Learning "en passant": The forgotten dimension. Paper presented at the Conference of the American Association of Adult and Continuing Education. Hollywood/Florida, 23. 10. 1986. ERIC Clearinghouse on Adult, Career, and Vocational Education. Columbus/Ohio 1986. http://www.reischmannfam. de/lit/1986-AAACE-Hollywood.pdf.

Reischmann, J. (2015a). Profesionalizacija obrazovanja odraslih - neki aspekti. (Professionalization of Adult Education - Some Aspects). Andragoške studije, (2), p. 23-37. Retrieved from http://www.as.edu.rs/search?l=sr\&n=2015-2

Reischmann, J. (2015b). Andragogy: Because "Adult Education" is not beneficial to the academic identity! In U. Gartenschlaeger \& E. Hirsch (Eds.), Adult education in an interconnected world (International Perspectives in Adult Education - IPE 71) (pp. 87-97). Bonn: DVV-International. Retrieved from http://www.reischmannfam.de/lit/2015-Andragogy-HeribertHinzen.pdf

SAvicevic, D. (1999). Understanding Andragogy in Europe and America: Comparing and Contrasting. In J. Reischmann, M. Bron, Z. Jelenc, Zoran (Eds.), Comparative Adult Education 1998: the Contribution of ISCAE to an Emerging Field of Study (pp. 97-119). Ljubljana: Slovenian Institute for Adult Education. Retrieved from http://files.eric.ed.gov/fulltext/ED430118.pdf

UNESCO (1997). CONFINTEA V: The Hamburg Declaration On Adult Learning. http://www.unesco.org/education/uie/confintea/declaeng.h 
Jost Reischmann ${ }^{3}$

Univerzitet u Bambergu u Nemačkoj

\section{Čemu sluze andragozi? Radna mesta, kompetencije, sadržaj studija, identitet}

Apstrakt: Ovaj rad ima želju da ojača identitet andragoga - da ih učini jakima i ponosnima. Polazi od opažanja da se termin „edukator odraslih” koristi za obeležavanje mnogo različitih funkcija, uloga, kompetencija i obrazovnih profila - što vodi nedefinisanom identitetu. Da bi se identitet uobličio, predlažemo da se izdiferenciraju različite grupacije koje rade u toj oblasti; fokus treba da bude na kadrovima obrazovanim na univerzitetu: andragozima. Radnim mestima smatramo mesta gde možemo naći uspešne univerzitetski obrazovane kadrove. Identifikovali smo četiri kompetencije koje su potrebne na tim radnim mestima: podučavanje, organizacija, konsalting i evaluacija. Te kompetencije moraju da budu uključene u obrazovanje buducih andragoga. Postavljamo sledeće pitanje: postoji li „objedinjujući koncept” za ljude koji rade u toj oblasti, neki identitet koji im je zajednički? Odgovor je: ono što je objedinjujuće jeste ideja, potreba i funkcija organizovanja promene: za pojedince, organizacije, društvo. Andragozi - bez obzira na to gde rade jesu specijalisti za promene. Da bi se ojačali samorazumevanje i profesionalni identitet kadrova univerzitetski obrazovanih za ovaj kompleksan poduhvat (i da im se omogući razlikovanje od 'svakoga' ko se bavi nekom vrstom edukacije odraslih), tu grupaciju treba nazivati andragozima. I treba im omogućiti da budu jaki i ponosni: u svetu koji se neprestano menja, specijalisti za promene su veoma potrebni.

Ključne reči: andragozi, edukatori odraslih, profesionalni identitet, kompetencije za andragoge, objedinjujući koncept za edukatore odraslih.

\footnotetext{
${ }_{3}^{3}$ Profesor (emeritus) Jost Reischmann bio je redovni profesor andragogije na Univerzitetu u Bambergu, u Nemačkoj, od 1993. do 2008. godine (jost.reischmann@uni-bamberg.de). Bio je predsednik i potpredsednik Međunarodnog društva za komparativno obrazovanje odraslih (ISCAE - www.ISCAE.org). Godine 1999. je nominovan, a zatim i uvršten u Međunarodni hol slave za obrazovanje odraslih i od 2006. do 2012. godine bio je član tamošnjeg odbora direktora. Godine 1998. je 'Primio predsedničku nagradu za inovativno liderstvo', a 2006. 'Nagradu za izuzetan doprinos' od Američke asocijacije za obrazovanje odraslih.
} 